Folds of Past, Present and Future 



\section{Folds of Past, Present and Future}

Reconfiguring Contemporary Histories of Education

Edited by Sarah Van Ruyskensvelde, Geert Thyssen, Frederik Herman, Angelo Van Gorp and Pieter Verstraete

\section{DE GRUYTER OLDENBOURG}


ISBN 978-3-11-062250-8

e-ISBN (PDF) 978-3-11-062345-1

e-ISBN (EPUB) 978-3-11-062372-7

Library of Congress Control Number: 2021939830

Bibliographic Information published by the Deutsche Nationalbibliothek

The Deutsche Nationalbibliothek lists this publication in the Deutsche Nationalbibliografie; detailed bibliographic data are available on the Internet at http://dnb.dnb.de.

(C) 2021 Walter de Gruyter GmbH, Berlin/Boston

Cover Image: Portrait of Marc Depaepe, 2010. Photo by Ginette Dumortier. Bellegem, Belgium. Used with the permission of Ginette Dumortier.

Printing and binding: CPI books $\mathrm{GmbH}$, Leck

www.degruyter.com 
Liber Amicorum for Emeritus Professor Marc Depaepe 
